\title{
Evaluation of Learning Center in Kindergarten
}

\author{
Yuliani Nurani \\ Early Childhood Education Program \\ Universitas Negeri Jakarta, Indonesia \\ yuliani.nurani@unj.ac.id
}

\author{
Sofia Hartati \\ Early Childhood Education Program \\ Universitas Negeri Jakarta, Indonesia \\ sofiahartati@unj.ac.id
}

\author{
Niken Pratiwi \\ Early Childhood Education Program \\ Universitas Negeri Jakarta, Indonesia \\ nikenpratiwi@unj.ac.id
}

\begin{abstract}
Learning activities for early childhood are carried out in an atmosphere of play. Structuring the playing environment becomes an important thing that needs to be prepared so that learning becomes more enjoyable. Central learning is one of the curriculum models that can be applied in PAUD institutions. TK Labschool Rawamangun-Jakarta Timur is one of the PAUD institutions that uses the center learning model. This study aims to evaluate the center learning by referring to the five components of learning, namely objectives, material, methods, media, and evaluation. The research was conducted at the labs I wanted to know at TK B Labschool Jakarta. The evaluation research model used is the Context, Input, Process, Product (CIPP) model developed by Stufflebeam, with a focus on research on process evaluation. The method used is the evaluation method with an evaluative descriptive approach, and quantitative. Data collection is done through observation, interviews, and documentation. Data analysis was performed in descriptive percentages. The main output of this study is in the form of an evaluation report on central learning, which can later become a basis for consideration in making a model of a central learning curriculum based on Indonesian local wisdom. The results of the study show that the learning center in kindergartens in the Jakarta area has already meet the standards of effectiveness or in other words it has been running effective. Effectiveness is measured by the achievement of five components, learning objective, material, methods, media and assessment.
\end{abstract}

Keywords: evaluation, learning center, kindergarten

\section{INTRODUCTION}

Playing for early childhood must be done in a fun way. Active, creative, innovative, effective and fun learning processes can be carried out by children prepared by educators through interesting, fun activities to arouse children's curiosity, motivate children to think critically. The learning center is a well-designed area, whose core learning is actively planned. The application of the central learning model provides freedom for children to choose play activities that have been prepared in one center.

Each center will be managed by one teacher and each group of children will move from one center to another every day. Management of classes in the center model is one room or place for one center. achievement of the central curriculum implementation starting from the central learning objectives, the readiness of teachers in applying the center to the central learning process is limited to five core components, namely objectives, material, methods, media and assessment in the hope that this research can be used as an evaluation and recommendation to the school.

The Beyond Centers and Circle Time (BCCT) model is part of the creative curriculum introduced in Indonesia by Phelps of the Florida Creative Center for Childhood Research and Training (CCCRT) (Guidelines for PAUD K-13 Class Management, 2015). The Center Model views play activities as an important process and in this case, educators have a role in facilitating children in developing children's active thinking skills. The Center Learning Model is a well-designed area, the core of which is active learning. The application of the center learning model provides freedom for children to choose play activities that have been prepared in one center. Each center will be managed by one teacher and each group of children will move from one center to another every day. Class management in the center model is one room or place for one center.

In this research the curriculum implementation center implementation will be evaluated from the learning objectives at the center, the teacher's readiness to apply centers to the learning process centers with limited to five core components, ;earning objectives, materials, methods, media and assessment with the hope that this research can be used as an evaluation and recommendations for the school in carrying out activities better learning.

\section{A. Learning Objective}

\section{LEARNING COMPONENTS}

In the learning process must have learning objectives that have been determined. Purpose is components that can affect other teaching components such as subject matter, teaching and learning activities, method selection, tools, resources, and evaluation tools (Djamarah and Zain, 2013). Because its role is so important then the goal is the first thing determined in learning. learning objectives will also be influential on the choice of material, teaching methods, as well as media will be used in the learning process.

So, the formulation needs to be done carefully and involve the whole teaching staff as well as education in schools. A learning process can succeed if 
it can achieve its objectives optimally and success is an indicator of teacher success in designing and implementing the learning process.

\section{B. Materials}

Learning material can be interpreted something the contents of the curriculum that must be mastered by students in the form of knowledge, skills, and attitudes through activities learning. The activity of organizing the material starts with selecting the material and arranging the material.

The material prepared must be understood by the child based on the objectives, through learning methods that are suitable for the child until the material can be accepted. Material is a core element of learning that includes knowledge, skills and attitudes delivered in teaching and learning activities by teachers to participants students in the classroom.

In learning for early children, the material is delivered in the form of themes arranged sequentially starting from one-year period teaching, one semester, one week to one day. The theme selection is will be delivered should be related to the child so learning will be more meaningful and not just a formality only.

\section{Methods}

Learning method is a way used by teachers in delivering a learning material. The method was chosen to facilitate the implementation of learning occur. Determination of the method is determined based on children's needs and adapted to the stage its development. This can make a child comfortable in the process of learning activities and will be influential towards the success of learning objectives.

The method is an attempt to implement the plan which have been arranged in real activities, it has been arranged optimally. Learning methods are achieved used in early childhood education include questioning methods answer, discussion method, demonstration method, game method, the method of telling stories, the method of field trips and the method of experimentation.

\section{Media}

In the teaching and learning process, the presence of a media has a significant meaning. The presence of media in the learning process will make class activities more interesting, interactive and fun, so indirectly the quality of learning too can be improved for the better.

Media is everything something that can be used to channel messages from the sender to the recipient so that it can stimulate thoughts, feelings, attention, and interests and attention students in such a way that the learning process occurs (Duludu, 2017).

The media can be used as an intermediary for the material to be conveyed by the teacher. In presenting a media can be in the form of audio, visual or audio visual. the media is an intermediary in delivery of messages, making it easier for children can understand what the teacher wants to achieve. Other than that, the media can also make children interested in learning.

\section{E. Assessment}

Evaluation is a process for determine the extent of the learning objectives already achieved or not by assessment. assessment is a process for get information about students by an institution in learning activities. The function of the assessment as feedback for educators on their performance in the management of learning, to see deficiencies in the use of various components of the learning system. In the learning process the determination and analyzing the five main components in the learning process will be seen whether the success of the learning process has been achieved.

\section{LEARNING CENTER MODEL}

Learning model is a pattern or a picture explain about various forms related to the activity. The model can also be interpreted as a whole learning system from beginning to end. Learning model can be a design that describes the details and creation of an environment that allows children to interact in learning so that development occurs in the child. A play center is a child's play zone or area equipped with a set of play tools that function as the environmental footing needed for develop all the basic potential of students in various aspects of development in a balanced manner.

Learning on this approach model, the teacher's role only as a facilitator, motivator and evaluator. Centers are special component, allowing children to participate in self-directed play activities (Isbell, 2008). Centers are defined as special components, allow children to participate in activities play independently. In this case, the center play activities can be do individually or in groups, aims to make children become more independent and learn independently, cooperative, so children who play and learn at the center can improve their potential skills.

The center is the center of learning activities or centers of learning resources is a deliberate vehicle designed for stimulates various aspects of development in children early (Nurani, 2010). Activities on this model are expected to be created learning that is not overbearing but enjoyable, so the child will more easily absorb what is studied in accordance with the principles of early childhood education is a play while learning. Besides, the center is also designed accordingly with the needs of children by observing each child development.

Learning center it supports children's learning and allows children to explore, experiment and interact with the environment accordingly with the stage of its development. Jackman also suggested a number of centers learning in early childhood classes, namely: (1) books, language, literacy, listening, and writing center; (2) dramatic play, home living area, or puppet center, (3) art center; (4) sensory activities with manipulatives; cooking; water; sand; and mud play; (5) blocks, (6) music and movements; (7) science, discovery, and nature; (8) math and manipulatives; (9) social studies / multicultural; and (10) computers / technology center (Jackman, 2012). this learning center can be combined or separated according to learning needs as well 
facilities owned by the school. central learning model a center of learning activities that can give children opportunities to play where the teacher as an educator presents the real world in the classroom and can encourage children to make connections between knowledge, experience and application in daily activity.

Learning Centers are centers of learning activities or learning resource centers which are a vehicle deliberately designed to stimulate various aspects of development in early childhood (Early \& Education, 2016). Because there are not only one developed aspect, the learning center consists of several centers. Activity centers allow children to individualize on their own initiative based on their skills and interests. So that children can choose the activities they want to do according to their interests (Yulisutiany, 2018).

The application of the learning center provides the opportunity for children to explore the environment around them in accordance with the stages of child development. Children can also choose activities that they think are interesting, so hopefully learning will be reconciled well and meaningfully (Adriany, 2017). Learning center is very child-centered where the teacher becomes a child supporter in the learning process by directing activities and preparing the footing of the playing environment.

\section{A. Science and Nature Center}

The science and nature center facilitate children to develop and extending the sensorimotor playing experience by providing a great deal opportunity for children to explore deep natural ingredients develop fine motor maturity needed in the process writing readiness, sports skills, and stimulating the work system child brain. The center is focused on development fine motor skills of children with activities that use a lot sense. As stated earlier, the material used in the center of natural materials in the form of natural ingredients obtained at the environment around the child. Goals of the center of science and nature learning include: (1) to learn about the natural environment; (2) to encourage experimentation with materials and tools; (3) to gain an appreciation for the use of scientific methods of inquiry, (4) to follow a systematic method for observing and recording information; and (5) to nurture an interest in nature and the environment in which they live (Isbell, 2008).

Learning at the science and nature center can stimulate the child's skills to solve problems independently by doing simple experimental activities or doing exploration of natural materials that are around children. Children can choose the play activities to be carried out in the center so knowledge received will be more meaningful because it corresponds to their interest. Therefore, the concept of new knowledge will be constructed in the learning process, in harmony with vocabulary acquisition new that children get. Science and nature center also provide useful for developing problem solving skills children scientifically, through deeper study and not only guess it. Children will get to know their surroundings with uses all of its senses. In addition, natural resource centers can also develop children's fine motor coordination through exploration activities in the center.

\section{B. Art Center}

The arts center has the aim of providing process experience quality learning, not just producing a work of art, develop skills, process creativity, and build basic art skills. Art center as the center of art activities is a playground for children to develop their development and knowledge. This center provides opportunities for children to develop a variety of children's skills by using various art tools and materials, which can be used for free play. The purpose of art centers is to provide process experience quality work, not producing a work of art.

Children also get pleasure from color exploration, fine motor skills and creativity processes, as well as building the ability of the basics of art. the play activities contained within the art center have been designed in such a way that play activities carried out by children will be fun by exploring the tools and materials contained in the arts center.

\section{Outdoor Center}

Outdoor center activities provide opportunity for children to practice individual skills that may have previously been conducted outdoors or in school sports rooms. With the center activities that have been set up with focus of physical activity, it can improve physical skills and interests when playing. outdoor center is an area already set by the teacher for play activities on students with the aim to improve physical skills on students, physically healthy students and develop other aspects, such as social emotional, cognitive, moral, and language.

Activities at the center not only train flexibility and muscle coordination alone, but rather social emotional aspects can be developed. This is in accordance with Sumantri opinion that the development of gross motor aims to: (1) improve movement skills; (2) maintain and improve physical fitness; (3) instill an attitude confident; (4) cooperate; and (5) behave in a disciplined, honest and sportive. Existing physical activity in early childhood is very good applied at school. This is because, activities in outdoor areas are not only gross motor skills that are developed but emotional social is also developed. A part from that, if gross motor development is inhibited then it will affect other developments.

\section{METHOD}

In the implementation of this first year's research using evaluation methods with qualitative and descriptive approaches. With the evaluation method the researcher is expected to provide an assessment of the implementation of learning centers in TK Labschool Rawamangun Jakarta. In addition, the evaluation method is also used to find out the quality of program things that have happened, then compared to a standard. The research design is used as an action plan to obtain data through questions to conclusions. In addition, this research is used as a kind of evaluation 
framework for collecting data, interpreting and making conclusions.

In this study, the evaluation model used is the Context, Input, Process, Product (CIPP) model developed by Stufflebeam. Context has meaning about the rules or conditions and the state of the institution implementing the program. Input means all program inputs, which include the characteristics of students, the characteristics of educators, and the facilities available. Process is the management of the learning process of students conducted by educators. Product is the result of students' learning process that is often seen in the ability of students in the form of an achievement index.

The CIPP model of evaluation activities is considered as a system so that one component with other components are interconnected. The process evaluation activities in this study were conducted to determine the achievement of five learning components, namely the objectives, materials, methods, media and evaluation centers at TK Labschool Rawamangun Jakarta. The implementation of learning centers with regard to the five learning components will be analyzed against the initial planning. Further information obtained will be processed to determine the effectiveness of learning related centers.

Criteria evaluation is developed more deeply when researchers are in the field or after conducting research and will be discussed again with supervisor. Thus, the criteria will be developed based on the results of observations, interviews, and documentation studies during at field.

Table 1.

Assessments Instrument

\begin{tabular}{|c|c|c|c|}
\hline \multirow{2}{*}{ No } & \multicolumn{3}{|c|}{ Assessment Criteria } \\
\hline & Aspect & Indicator & Item \\
\hline 1 & $\begin{array}{l}\text { Learning } \\
\text { Objective }\end{array}$ & $\begin{array}{l}\text { Planning goals learning and } \\
\text { implementation learning }\end{array}$ & 4 \\
\hline \multirow[b]{2}{*}{2} & \multirow[b]{2}{*}{ Matherials } & $\begin{array}{l}\text { A conceptual foundation for } \\
\text { document curriculum } \\
\text { guidelines }\end{array}$ & \multirow[b]{2}{*}{9} \\
\hline & & $\begin{array}{l}\text { Semester planning, Weekly } \\
\text { planning, and daily planning } \\
\text { arranged according to the } \\
\text { theme }\end{array}$ & \\
\hline \multirow[t]{2}{*}{3} & \multirow[t]{2}{*}{ Methods } & $\begin{array}{l}\text { Implementing structuring steps } \\
\text { in environment play according } \\
\text { to curriculum standards }\end{array}$ & \multirow[t]{2}{*}{4} \\
\hline & & $\begin{array}{l}\text { Using a variety of methods } \\
\text { varies with each activity }\end{array}$ & \\
\hline 4 & Media & $\begin{array}{l}\text { Play equipment or suitable } \\
\text { media with the theme of the } \\
\text { activity }\end{array}$ & \\
\hline \multirow{3}{*}{5} & \multirow{3}{*}{ Assesment } & Daily report & \multirow{3}{*}{6} \\
\hline & & Monthly report & \\
\hline & & Parens's feedback & \\
\hline \multicolumn{3}{|c|}{ Total Item } & 28 \\
\hline
\end{tabular}

Data collection is done through observation, interviews, and documentation. Data analysis was performed in descriptive percentages. Data already obtained at school, researchers conducted descriptive statistics that function to describe or provide an overview of the object under study through sample data or population as they are, without analyzing and make conclusions that apply to the public. In addition, it is used descriptive percentage to describe each indicator in each component using the formula.

\section{RESULT AND DISCUSSION}

This research was conducted in Labschool Kindergarten Jakarta is a Child Education institution Early age formal pathway located at Jalan Pemuda, Jakarta State University (UNJ) Rawamangun East Jakarta. The name TK Labschool Jakarta is under the auspices of the Foundation Pembina Jakarta State University which contains meaning history in it namely Labschool stands for Laboratory School TK Labschool Jakarta implements the program learning with the center approach since 2010 .

Learning centers at TK Labschool are discussed further to find out their effectiveness learning with limited to five learning components. The following is a discussion of research in the form of based analysis five learning components:

\section{A. Learning Objective}

Purpose of which contained in the analysis of themes and activities of the centre know refers to Terminology, Facts, and Principles (TFP), which is what knowledge wants achieved from a material. Discussion on TFP are in the syllabus. The learning objectives at the center have been fully written using operational verbs. Learning activities, methods, media, and the assessment conducted refers to the learning objectives. This is seen from the position planning learning objectives carried out first.

Learning objectives are made in general to specifically the activities in the labs I want to know. This can be found in the analysis of themes and labs activities I want to know. Based on the results analysis of the learning objectives component in the labs I want to know belongs to very effective.

\section{B. Materials}

Learning materials at the center have been arranged in a manner systematically follows the major themes to conical sub-themes which is divided in each center. Planning activities in the labs I want to know referring to knowledge related sub-themes to be studied and analyzed in the theme and activity analysis tables. Teacher the center also presents learning material by adjusting in aspects of child development. Based on the results of component analysis learning materials in the labs I want to know classified as very effective.

Material will be delivered at during the initial activity by explaining the themes and sub themes, then the material expands children's knowledge with a joint discussion. On the delivery of this material carried out systematically, in detail and in accordance with syllabus planning and daily activities. In addition, activities learning is also in accordance with the foothold of learning centers

\section{Methods}

Learning methods at the center are chosen based on planned activities. This is because of the method is a method that can be used by the teacher in delivering 
existing knowledge. It's just that development is only fixated on conversational methods, questions and answers, direct assignments, and experiment. Also not available yet is a source citation document learning used. Nevertheless the application of the method learning by the labs teacher I want to know is adapted to characteristics of early childhood. Based on the results of component analysis learning methods in center classified as very effective.

Learning methods using several methods including discussion, ask answer, then practice right away. Basically, in activities, at the core of each of these centers, the teacher puts forward the method direct practice to gain direct experience on child. So, children will always be involved in activities. Besides that, activities at the center are all with play and can be varied as attractive as possible with teacher creativity. As for the beginning and end activities, the teacher always uses discussion and questioning techniques responsible for discussing material and evaluating activities which has been done.

\section{Media}

Learning methods at the center are chosen based on planned activities. This is because of the method is a method that can be used by the teacher in delivering existing knowledge. It's just that development is only fixated on conversational methods, questions and answers, direct assignments, and experiment. Also, not available yet is a source citation document learning used. Nevertheless, the application of the method learning by the labs teacher I want to know is adapted to characteristics of early childhood. Based on the results of component analysis learning methods in center classified as very effective.

\section{E. Assessment}

Assessment or assessment of learning conducted at each center follows the assessment guidelines owned by TK Labschool. The center assessment sheet refers to the Level Standard indicator Child Development Achievement (STPPA) contained in the syllabus. Where the STPPA formulation can be found in the theme analysis and activities in each center. Because of time constraints, and there are a lot of activities to get assessment data conducted by the teacher center after learning activities in each center done. While the overall assessment document will be distributed to each class after the center round is over.

However, some documents have not been arranged completely in class files, like the learning procedure. In general data both inside and outside the center have been recapitulated into data weekly, monthly, until semester. Based on the results analysis of the evaluation components of learning in center quite effective.

Furthermore, after obtaining a value based on five components, then its value can be combined from five components. The value obtained on the effectiveness of learning the center in the outbound labs is 63 of value the maximum is 76 . Effectiveness results learning center in TK Labschool Jakarta is $82.89 \%$ which shows an interval of $81.25 \% \leq \% \leq$
$100 \%$ (B.III.F). It can be concluded that the learning center at TK Labschool Jakarta can be classified very effective.

\section{CONCLUSION}

The results of this study provide an overview of the application learning center in Labschool Kindergarten Jakarta. Based on research that has been done is known if the effectiveness center learning tends to be very effective. Theoretically effective learning is learning can achieve the learning objectives. The purpose here is planning a learning program designed before learning begins. Implementation between one learning component with other learning components determine the effectiveness of a learning. This shows the implications of learning component of the effectiveness of learning as a whole.

Practically the implementation of learning in the labs I want know has referred to the plan contained in the syllabus learning. Each component is explained in terms of systematic starting from the syllabus document to the daily activity document (RKH) and the center activity plan (RKS). Based on the results of this study, then given advice to the school, teachers, and also further researchers to be able to continue to improve the quality of learning centers that are in accordance with the characteristics of early childhood.

\section{REFERENCES}

[1] Adriany, V. 2017. The Internationalisation of Early Childhood Education: Case Study from Selected Kindergartens in Bandung, Indonesia. 18,1-16. https://doi.org/10.1177/1478210317745399.

[2] Catron, C. E., and Allen, J. 1999. Early Childhood Curriculum: A Creative Play Model. NewJersey: Merill Publ.

[3] Djamarah, S. B., and Zain, A. 2013. Strategi Belajar Mengajar. Jakarta: Rineka Cipta.

[4] Dodge, D. T., \& Colker, L. J. 2000. Creative Curriculum for Early Childhood. Washington, DC: Teaching Strategies.

[5] Early, I. 2016. The Application of Beyond Centers and Circle Time Approach, 1(1), 81-90.

[6] Isbell, R. 2008. The Complete Learning Center Book, USA:Gryphon House.

[7] Jackman, H. 2009. Early Education Curriculum: A Child's Connection to the World. USA. Thomson Delmar Learning.

[8] Newberry, J., Hickey, M., \& Bunnell, T. 2012. Durable Assemblage: Early Childhood Education in Indonesia, (194).

[9] Nurani, Y., and Sujiono, B. 2012. Bermain Kreatif Berbasis Kecerdasan Jamak. Jakarta: Indeks.

[10] Konsep Dasar Pendidikan Anak Usia Dini. 2012. Jakarta: Indeks.

[11] Coughlin, P. A. 2000. Menciptakan Kelas yang Berpusat pada Anak 3-5 Tahun. Jakarta: Indeks.

[12] Sutikno, M. S. 2014. Metode dan Model-model Pembelajaran: Menjadikan Proses Pembelajaran Lebih Variatif, Aktif, Inovatif, Efektif dan Menyenangkan. Lombok: Holistica.

[13] Yulisutiany, I. 2018. Study of Education Competency and Effect on Learning Process of BCCT Method on Educational Group of Education Age (PAUD) in Sukasari Bandung, 3(2), 69-77. https://doi.org/10.20448/2003.32.69.77. 